\title{
Cultural significance of the flora of a tropical dry forest in the Doche vereda (Villavieja, Huila, Colombia)
}

\author{
Jeison Herley Rosero-Toro', Luz Piedad Romero-Duque ${ }^{1}$, Dídac Santos-Fita ${ }^{2 *}$ (D) and Felipe Ruan-Soto ${ }^{3}$
}

\begin{abstract}
Background: In Colombia, ethnobotanical studies regarding plant cultural significance (CS) in tropical dry forests are scarce and mainly focused on the Caribbean region. Different authors have indicated that the plants with the most uses are those of greater cultural importance. Additionally, gender differences in knowledge and interest in natural resources has been widely recorded. This study evaluated the cultural significance of plants in the Doche community, in the Department of Huila. Furthermore, it evaluates the richness of plant knowledge among local inhabitants, looking for testing the hypothesis that the CS of plants positively correlates to the number of uses people inform about, and that there are significant differences on the richness of ethnobotanical knowledge between men and women in this community.
\end{abstract}

Methods: The ethnobotanical categories: "food," "condiment," "economy," "fodder," "firewood," "timber", "medicine," and "others" were established to carry out semi-structured interviews, social cartography, and ethnobotanical walks. The frequency of mention was calculated as a measure of CS. The richness of knowledge of each collaborator was obtained. Non-parametric tests were performed to determine whether differences between the numbers of mentioned species existed between genders and ethnobotanical categories. Finally, Pearson correlation tests determined the relationship between CS and the number of ethnobotanical categories.

Results: A hundred useful species were registered in crops and forests. The most abundant categories were medicinal (45 species), firewood (30), and fodder (28). The most culturally significant species according to frequency of mention were Pseudosamanea guachapele, Guazuma ulmifolia, Manihot esculenta, and Musa balbisiana. The species with the most registered uses (five) were Guazuma ulmifolia and Gliricidia sepium. We found a correlation between CS and the number of uses per ethnobotanical category, but no significant difference between genders regarding ethnobotanical knowledge.

Conclusion: Frequency of mention provides relevant information about the CS of species. Furthermore, it aids to establish sustainable use of tropical dry forests without loss of resources parting from strategies designed from within the Doche community and based on their ethnobotanical knowledge. We found that the number of uses of a plant is correlated with its degree of cultural importance. On the other hand, no significant differences were found between genders regarding ethnobotanical knowledge; that is, both men and women have similar roles in the community, which allows them to recognize the same uses per species.

Keywords: Ethnobotany, Cultural significance, Use and management, Tropical dry forest, Colombia

\footnotetext{
*Correspondence: dsantofi@gmail.com

${ }^{2}$ Asociación Etnobiológica Mexicana A.C., Calle Profesor Felipe W. Mijangos,

Colonia 12 de Junio, E-29243 San Cristóbal de Las Casas, Chiapas, Mexico

Full list of author information is available at the end of the article
} 


\section{Background}

The services provided by ecosystems are valued differently by different actors according to socio-ecological contexts and cultural and economic interests $[1,2]$. The measure of this value can be ecologic, economic, and socio-cultural [3]. This last category has become a relevant tool to learn of the significance and the benefits that ecosystems provide to human communities, resulting in a combination of social perception and the capacity of an ecosystem to satisfy the needs of human groups [4-6]. While this information does not necessarily mean a monetary estimation of the services, it does reflect the relevance of the services provided [4]. Thus, cultural significance can be a valuable tool for such purposes of evaluating ecosystem services [7].

The cultural significance of a species has been defined by Hunn [8] as the value or role it has within a particular community; this includes species with high and low relevance for a social group and it may vary according to use and appreciation of a species by people [9, 10]. Research on cultural significance has used for different research approaches, using different methods: participant techniques, group interviews, community workshops, participant observation, academic and community group opinions, and others $[11,12]$. From quantitative ethnobotany, numerous ways to evaluate the significance of a particular taxon have been proposed, the most popular of which are those based on informant consensus [13, 14]. The most popular indicators in these cases include frequency of mention [15].

Different ethnobotanical studies have speculated about the features that plant species that are considered highly culturally significant must share. Aspects such as availability [16-18], features of their biological cycle [19], or other specific features such as biomass and size [20], to mention some few, have been explored as factors that might explain cultural significance. For some researchers, the more uses a plant has (either as food, construction material, medicine, religious objects, or any other) the greater its degree of cultural significance is $[16,21,22]$. Therefore, the sum of uses is a very widespread method, which allows to quickly quantify the importance of species [22].

On the other hand, indexes like the Knowledge Richness Index have been used to evaluate the degree of knowledge a user has about the possibilities of their useful flora and whether significant differences exist in the knowledge of different sociodemographic sectors [23, 24], given that clearly different social groups have different roles that could affect the amount and quality of knowledge of useful flora [24-26]. For gender, different authors have reported that preferences on plant species, as well as the general interest in natural resources, may be different in men and women and, therefore, both have different priorities in the management of natural resources [27]. Particularly from ecofeminism, it is postulated that women, through their daily activities, have a more intense bond with their environment, which makes them carriers of a special interest in the conservation of nature and gives them extensive knowledge about the natural resources that surround their communities [28].

In Colombia, ethnobotanical studies have dealt with inventories of useful flora [29-31] and agro-biodiversity in traditional production systems [32, 33]. Studies of ethnobotany in tropical dry forests are scarce and have been focused on the Caribbean region, mainly reporting inventories of uses and vernacular names for useful plants [34-36]. Thus far, research in the department of Huila has been mainly centered in analyzing the functional and nutritional properties of Passifloraceae [37], as well as identifying the non-timber forest resources with the greatest potential for medicine and commerce in the mid and lower basins of Las Ceibas river [38]. In the Doche vereda, where this study was carried out, there is around $35.3 \%$ of tropical dry forest left [39]. The strong pressure that is put on this ecosystem through timber, fodder, and firewood extraction along with the different agricultural activities supporting economic and subsistence activities have caused the ecosystem services to be less available and accessible to the community. Furthermore, no studies have evaluated the most culturally significant species in this community, the features these plants share, or whether knowledge differs between men and women.

In this context the following questions arise: What are the used species in the Doche community with the greater cultural significance (CS)? Can the number of uses a plant has be a factor that explains its CS? And, is the richness of knowledge about these species different for men and women? This study aims to determine the CS of different used plants in the Doche community in the Huila Department in Colombia. Furthermore, it evaluates the richness of plant knowledge among its inhabitants, testing the hypothesis that the CS of plants positively correlates to the number of uses they are given and that there are significant differences on the richness of ethnobotanical knowledge between men and women in this community.

\section{Methods}

Study area

This study was carried out in the Doche vereda, old Doche Hacienda located in the eastern portion of the municipality of Villavieja (Huila, Colombia) located at $3^{\circ} 17^{\prime} 5.07^{\prime \prime}$ 
North and $75^{\circ} 3^{\prime} 25.11^{\prime \prime}$ West (Fig. 1), with an extent of 3870.6 ha [40]. The area has a transitional climate spanning from warm-dry to warm-very dry; the mean monthly temperature is $28{ }^{\circ} \mathrm{C}$ with scarce rains. The vegetation is that of a tropical dry forest, where average annual temperature is $\geq 25{ }^{\circ} \mathrm{C}$, annual rains span from 700 to $2000 \mathrm{~mm}$, and there are three or more dry months during the year (rain $<100 \mathrm{~mm} /$ month) [41].

Fandiño and Wyngaarden [40] registered a population of 79 inhabitants, and according to the Development Plan for Villavieja [42], 18 residences can be found there. According to estimations in the field, there are around 60 people currently living in Doche. Although agriculture and stockbreeding have grown following the creation of an irrigation system, these activities have decreased. Because of this situation, people have migrated to other regions within this department. The residents of this area depend on the sale of rice, bananas, sweet potato, and cocoa, and, to a lesser degree, on goat and sheep stockbreeding for family sustenance.

\section{Data collection and analysis}

Between December 2015 and August 2016, we worked with 18 people (seven men and 11 women) belonging to 12 families. The community authorized the use of all data obtained via the proposed methodologies through previous, free, and informed consent. The participants were selected following three criteria: (a) being current residents of Doche, (b) carrying out activities related to natural resource use in the study area, and (c) having time availability to participate in the project.

To register the cultural value of useful flora in the tropical dry forest, eight ethnobotanical categories were established; these were "food" (cultivated and wild edible species), "condiment" (species used as additional ingredients to prepare food), "economic" (species generating an income by being sold), "fodder" (species used as livestock food), "firewood" (species used for heating to cook food), "timber" (species used for construction to make beams, fences, or other things), "medicine" (species that prevent or cure ailments in humans), and "others" (useful species that are not included in the aforementioned categories). Based on these categories, the semi-structured interviews were carried out [43] among participants to recognize species of cultural significance.

To establish the cultural significance (CS) of plant species, those interviewed listed the most important species in each ethnobotanical category and their frequency of being mentioned was calculated [44-46]

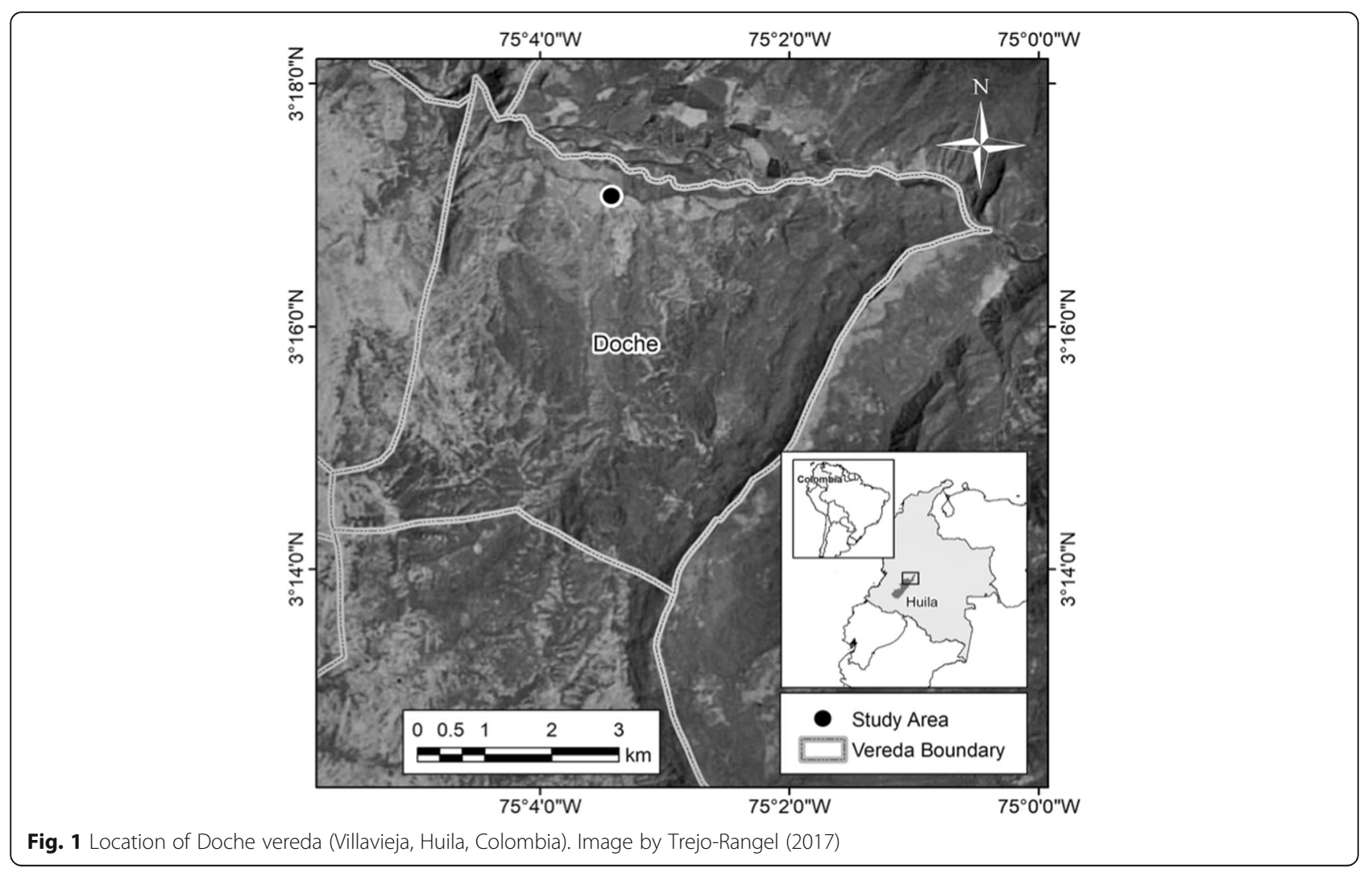


by adding the number of times each species was mentioned [47, 48].

Additionally, the Knowledge Richness Index (RQZ) was calculated to estimate the richness in the knowledge of each person about the uses of plants in their region [23]. For accomplishing such purpose, the following equation was used:

$$
\mathrm{RQZ}=\frac{\mathrm{EU}}{\text { maximum EU value }}
$$

In this equation, $\mathrm{EU}=$ the number of useful species to make up for services reported by a participant and maximum $\mathrm{EU}$ value = total number of useful species needed to make up for reported services in the region by all participants. The value of this index varies between zero and one, where one represents the maximum knowledge of useful plants in the region.

The results from the interviews were analyzed with non-parametric $U$ Mann-Whitney tests [49] to determine whether differences exist in the number of mentioned species between genders and between ethnobotanical categories. Likewise, Pearson correlations were calculated to determine whether a greater CS (obtained through the frequency of mention) would include the species included in the greater number of ethnobotanical categories. These statistical analyses were performed using Minitab 16. Additionally, a Principal Coordinates Analysis (PCO) was carried out to determine the similarity of the reported useful flora between interviewed people and ethnobotanical categories. This analysis was carried out using the 2.11 version of the Numerical Taxonomy and Multivariate Analysis System (NTSYSPC) software [50].

Finally, a social cartography workshop was carried out [51] to find the areas from which plant species are extracted. To recognize the known vegetation's vernacular names, ethnobotanical walks were taken in the usage areas in order to identify useful species [51]. Plant material that was not identified in the field was collected and registered in photography for botanical backup. The determination of plants was carried out in the biological collection at the Universidad de Ciencias Aplicadas y Ambientales (UDCA) in Bogota, using the TROPICOS platform to corroborate current scientific names. These specimens were not included in the biological collection due to their lack of minimal required features, such as flowers and/or fruits.

\section{Results}

We found that the areas in which species are used by the Doche community are croplands and cattle areas up to a hectare in extension. These are located in tree-covered savannah and the banks of Cabrera river (Fig. 2a, b), and the wooded area spanning from the tree-covered savannah to the conservation area called Cerro Saltarén, where logging and herding activities take place (Fig. 2c, d). In croplands, 58 plant species are used, while 34 species come from

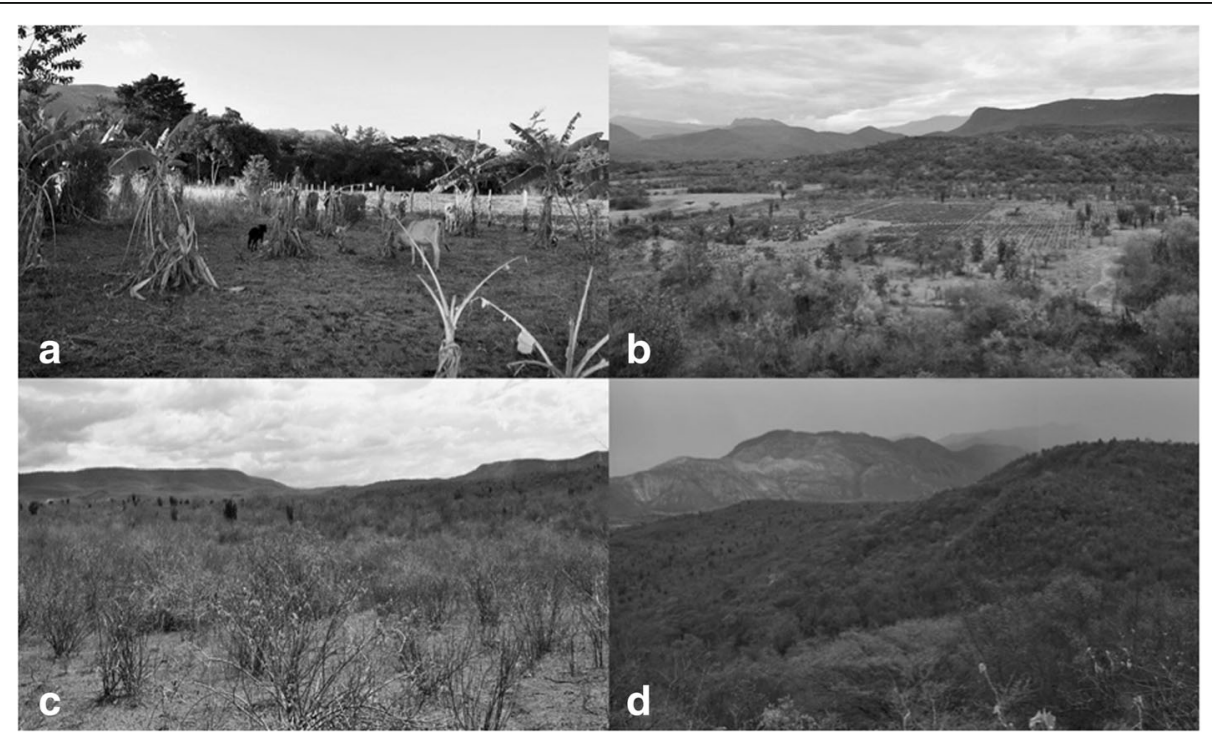

Fig. 2 Areas in which vegetable species are used in the Doche community (Villavieja, Huila), both croplands and forests. a Location of the cropland along the banks of the Cabrera river and $\mathbf{b}$ in the tree-covered Savannah. The forest area is located between the $\mathbf{c}$ tree-covered Savannah and d Cerro Saltarén (photos by J. H. Rosero-Toro) 
forests; eight species can be found in both environments (Appendix).

Regarding the access to utilized flora, it is currently allowed to $\log$ only two individuals of wild timber species per family each year, while no limitations are set for firewood species. Approximately $75 \%$ of the families interviewed extract timber once or twice a week, while $25 \%$ of them seek this resource three or four times a week. Fodder material is extracted daily by $35 \%$ of the families, while $47 \%$ of them extract it once or twice a week, and $18 \%$ only three to four time a week. Contrastingly, the interviewed population showed no knowledge of the magnitude of use of species in the food, condiment, economy, medicine, and others categories.

In all, 100 species of used flora were recorded. These belong in 94 genera and 39 families; four species were not taxonomically identified since they were not found in the study area (see Appendix). The most used family was Fabaceae, which included 13 genera and 15 used species, while 24 families included only one used species each. The timber category groups 20 species. From these, the interviewed population prefers cedro (Cedrela odorata) and coyo (Trichilia sp.); however, these species have a low availability of individuals so their use is restricted. Thus, species growing on croplands such as bili bil (Guarea guidonia), cachimbo (Erythrina fusca), and matarratón (Gliricidia sepium) are often used instead.

Meanwhile, the firewood category grouped 30 species: varazón (Casearia tremula), balso (Heliocarpus americanus), siete cueros (Machaerium sp.), and tachuelo (Zanthoxylum sp.) are exclusive to this category. Other species of interest were amargoso (Aspidodera cuspa), payandé (Pithecellobium dulce), cachimbo, matarratón, guácimo (Guazuma ulmifolia), and cuchiyuyo (Trichanthera gigantea) (see Appendix). This category shares 13 species with fodder, which contains 28 species. In cropfields both cultivated (leucaena and caña) and wild species typical to tropical dry forests (pela and amargoso) are found.

The medicine category grouped the most species, 45 , which are used for 32 different treatments. We found that a single species can be used for more than one treatment: such is the case of sábila (Aloe vera), consuelda (Pseudelephantopus spiralis), and chisaca (Tridax procumbens). The most used parts of the plant were twigs (52\%) and leaves (26\%). The most frequent forms of use were aromatic (57\%) and poultice (15\%), while the most frequent forms of application were oral $(73 \%)$, external $(15 \%)$, and in baths (6\%) (Table 1).

In the food category, 20 species were registered. Of these, piñuela (Bromelia penguin) and cabeza de negro
(Melocactus curyispinus) are not cultivated. Thirteen of these are also included in the economy category, among them are yuca (Manihot esculenta) and plátano (Musa balbisiana). Commerce of these species is carried out within the community of Doche vereda and in the municipality of Villavieja. The category others grouped 15 species, such as nim (Azadirachta indica), gomo (Cordia dentate), and cruceto (Randia aculeate). These species have diverse uses, such as insecticide, mouse poison, and home utensils. The category with the smallest amount of species in it is condiment, which includes five cultivated species (see Appendix).

Species with the greatest cultural significance according to their frequency of mention were Pseudosamanea guachapele (mentioned 18 times), Guazuma ulmifolia (17), Manihot esculenta and Musa balbisiana (16), and Acacia farnesiana and Pithecellobium dulce (15).

Species with the most uses were Guazuma ulmifolia and Gliricidia sepium each with five registered uses. Other multiple-use species are Trichanthera gigantea, Annona muricata, Cordia dentata and Theobroma cacao, each with four uses and, after these, 15 species with three uses, 26 species with two, and 53 species with only one registered use (see Appendix).

The results from the Pearson correlation coefficient found that there is a moderately positive relation $(r=0$, 64; $p<0.001$ ) between cultural importance and the number of ethnobotanical categories.

On the other hand, the Principal Coordinates Analysis (PCO) test made two interviewed groups. Most of the collaborators were in group A, while group B only included two interviewed persons (JT05, MI06) (Fig. 3). Furthermore, the PCO per ethnobotanical category also formed two groups (Fig. 3b); principal coordinate 1 discriminates the "timber", "firewood", "fodder", and "others" grouping them apart from the "economic" and "food" categories.

The greatest Knowledge Richness (RQZ) was registered in three individuals (MI06, IG16, and JT05), each reaching a 0.35 value (Table 2). No significant differences between gender were found for RQZ values $(p=0,6184)$. Similarly, no significant differences were found between genders within ethnobotanical categories (economy, $p=0.4011$; fodder, $p=0.2152$; firewood, $p=0.3813$, timber, $p=0.4876$; condiment, $p=$ 0.1872; food, $p=0.3133$; medicinal, $p=0.8904$; and others, $p=0.5442)$.

\section{Discussion}

Of the useful flora in the Doche vereda, the family Fabaceae has the greatest diversity of genera and species, as has been formerly found in tropical dry 
Table 1 Ailment, form of preparation, and form of application of useful medicinal plants identified by inhabitats of the Doche vereda (Villavieja, Huila)

\begin{tabular}{|c|c|c|c|c|}
\hline Common name & Scientific name & Used part & $\mathrm{FP} / \mathrm{FA}$ & Ailment function \\
\hline Abreojo & Alternanthera sp. & Tw & De/Or & Cough \\
\hline Aguacate & Persea americana Mill. & $\mathrm{Fr}$ & De/Or & Circulation \\
\hline Albahaca & Ocimum basilicum L. & Tw & To, De/Or, Ex & Tired eyes, diarrhea \\
\hline Amansa guapo & Justicia pectoralis Jacq. & Le & $\mathrm{Ar} / \mathrm{Or}$ & Relaxing \\
\hline Anamú & Petiveria alliacea $\mathrm{L}$. & Tw & De/Or & Ulcer, cancer \\
\hline Anón & Annona squamosa $\mathrm{L}$. & Le & De/Or & Vesicle \\
\hline Cacao & Theobroma cacao (Mill.) Bernoulli & $\mathrm{Fr}$ & De/Or & Migraine \\
\hline Caléndula & Calendula sp. & Tw & $\mathrm{Ar} / \mathrm{Or}$ & Relaxing \\
\hline Chisacá & Tridax procumbens $\mathrm{L}$. & Tw & De/Or & Antipyretic, cough \\
\hline Cilantro cimarrón & Eryngium foetidum $\mathrm{L}$. & Tw & De/Or & Hepatitis \\
\hline Ciruelo & Spondias sp. & Tw & $\mathrm{Ju} / \mathrm{Bt}$ & Antipyretic, dysuria \\
\hline Consuelda & Pseudelephantopus spiralis (Less.) Cronquist & Tw & Po, Ju/Ex & Anti-inflammatory, eye cleansing \\
\hline Cuchiyuyo & Trichanthera gigantea (Bonpl.) Nees & Le & $\mathrm{De} / \mathrm{Bt}, \mathrm{Or}$ & Acne, cleansing the blood \\
\hline Desinchadera & Desmanthus virgatus (L.) Willd. & Tw & Po/Ex & Anti-inflammatory \\
\hline Encaje & $\mathrm{N} / \mathrm{l}$ & Tw & De/Or & Dysuria \\
\hline Escoba & Sida rhombifolia Mast. & Tw & De/Or & Diarrhea \\
\hline Gomo & Cordia dentata Poir. & $\mathrm{Fl}$ & De/Or & Cough \\
\hline Guácimo & Guazuma ulmifolia Pers. & Le & De/Or & Diarrhea \\
\hline Guanábano & Annona muricata $\mathrm{L}$. & Le & Po/Ex & Anti-inflammatory \\
\hline Guayaba cimarrón & Psidium guineense SW. & $\mathrm{Fr}$ & De/Or & Kidney \\
\hline Hita moreal & $\mathrm{N} / \mathrm{l}$ & St & Ju/Ex & Earache \\
\hline Insulina & $\mathrm{N} / \mathrm{l}$ & Tw & Ju, De/Ex, Or, Bt & Diabetes, kidney, abscesses \\
\hline Limón & Citrus $\times$ limón (L.) Osbeck & Le & De/Or & Abdominal pain, diarrhea \\
\hline Limoncillo & Cymbopogon citratus (DC.) Stapf & Tw & De, Ar/or & Abdominal pain, diarrhea, relaxing \\
\hline Mango & Mangifera indica $\mathrm{L}$. & Le & Po/Ex & Anti-inflammatory \\
\hline Marañón & Anacardium occidentale $\mathrm{L}$. & Tw & De/Or & Cough \\
\hline Matarratón & Gliricidia sepium Kunth ex Steud. & Le & De/Or & Antipyretic \\
\hline Moringa & Moringa oleifera Lam. & Le & $\mathrm{Ar} / \mathrm{Or}$ & Relaxing, colon \\
\hline Mosquero & Croton pedicellatus Kunth & Tw & $\mathrm{De} / \mathrm{Bt}, \mathrm{Or}$ & Diarrhea \\
\hline Naranjo & Citrus $\times$ sinensis (L.) Osbeck & Le & De/Or & Accelerates labor \\
\hline Orégano & Origanum vulgare L. & Le & De/Or & Tension \\
\hline Papaya & Carica papaya $\mathrm{L}$. & $\mathrm{Fr}$ & NP/Or & Colon, gastritis \\
\hline Pelá & Acacia farnesiana Wall. & $\mathrm{Ro}, \mathrm{Ba}$ & $\mathrm{De} / \mathrm{Bt}$, Or & Antipyretic \\
\hline Piñón & Jatropha curcas (Adans.) Griseb. & $\mathrm{Fr}$ & NP/Or & Purging \\
\hline Pringamosa & Cnidoscolus urens (L.) Arthur & $\mathrm{Fl}$ & $\mathrm{Ar} / \mathrm{Or}$ & Cough \\
\hline Pronto alivio & Lippia alba (Mill.) N.E. Br. ex Britton \& P. Wilson & Tw & $\mathrm{Ar} / \mathrm{Or}$ & Abdominal pain, relaxing \\
\hline Sábila & Aloe vera (L.) Burm. f. & Le & De, Ju/Or & Prostate, diabetes; cough, gastritis, hair loss \\
\hline Simecojé & Momordica charantia L. & Tw & De/Or & Gastritis, antipyretic \\
\hline Tomillo & Thymus sp. & Tw & De/Or & Cold, cough \\
\hline Toronjil & Melissa sp. & Tw & $\mathrm{Ar} / \mathrm{Or}$ & Relaxing \\
\hline Verbena & Verbena litoralis Kunth & Tw & Ju/Or & Antipyretic \\
\hline Verdolaga & Portulaca sp. & Tw & De, Ju/Or & Dysuria, ulcer \\
\hline
\end{tabular}


Table 1 Ailment, form of preparation, and form of application of useful medicinal plants identified by inhabitats of the Doche vereda (Villavieja, Huila) (Continued)

\begin{tabular}{lllll}
\hline Common name & Scientific name & Used part & FP/FA & Ailment function \\
\hline Yerbabuena & Mentha spicata L. & Tw & Ar, De/Or & Abdominal pain, diarrhea, vomit \\
Yuquillo & $\mathrm{N} / \mathrm{I}$ & Tw & De/Or & Cancer \\
Sasafrás & Bursera tomentosa (Jacq.) Triana \& Planch. & Tw & De/Ex, Bt & Mosquito bites, rheumatism
\end{tabular}

Used part: Ba bark, Fl flower, Fr fruit, Le leaf, Tw twig, Ro root, St stalk. FP form of preparation: Ar aromatic, De decoction, Po poultice, To topical, Ju juice, NP no preparation. FA form of application: Bt baths, Ex external, Or oral, N/I not identified

forests of Huila [39, 52-54], in the Caribbean and in the dry valley of Magdalena river [55, 56]. Plants from this family are considered pioneers in the lowlands of the Neotropics, tropical dry forests, and arid and semi-arid zones [57, 58]. The use of legumes has physiological advantages by producing favorable habitats for the establishment of other species [59], their potential to become fodder, and being a relevant alternative in the management of areas and soil restoration [29, 52].

Regarding usage areas, the relevance of cropfields proved to be related to the coverage of immediate needs of the local population, by finding a greater availability and easy access to resources in these areas $[49,60]$. Because of climate conditions in the area, farming these species guarantees resources that are relevant to the community for their role in covering basic needs. The relevance of cropland in peasant communities has been documented by Zuluaga and Ramírez [33], who found that these spaces contain and preserve a high agrodiversity, as well as accumulated knowledge that is a product of the experience of peasants adapting to production systems. These authors also reported 64 species in croplands, a similar number to that found in this work. Regarding the use of species within forests, a lower use to

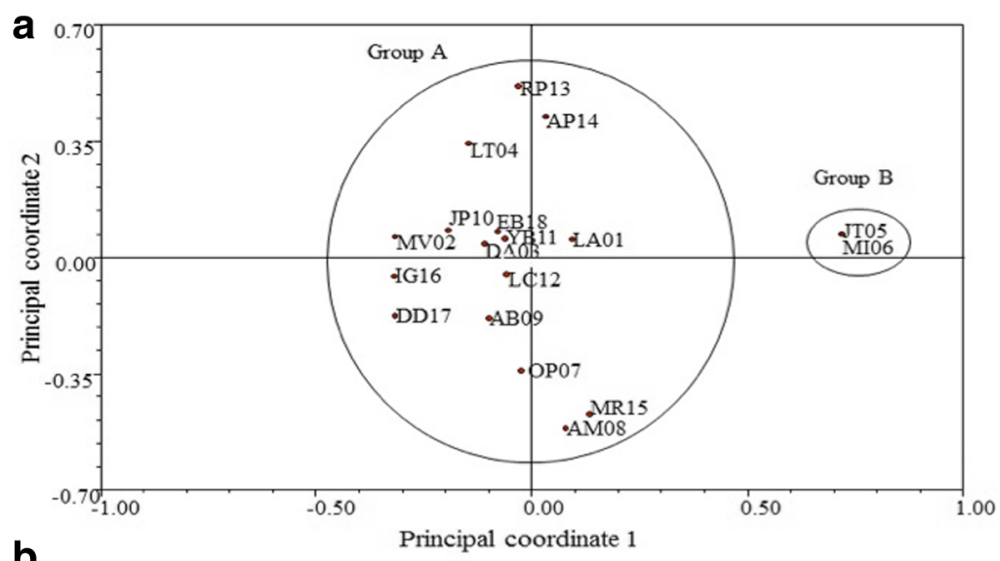

b

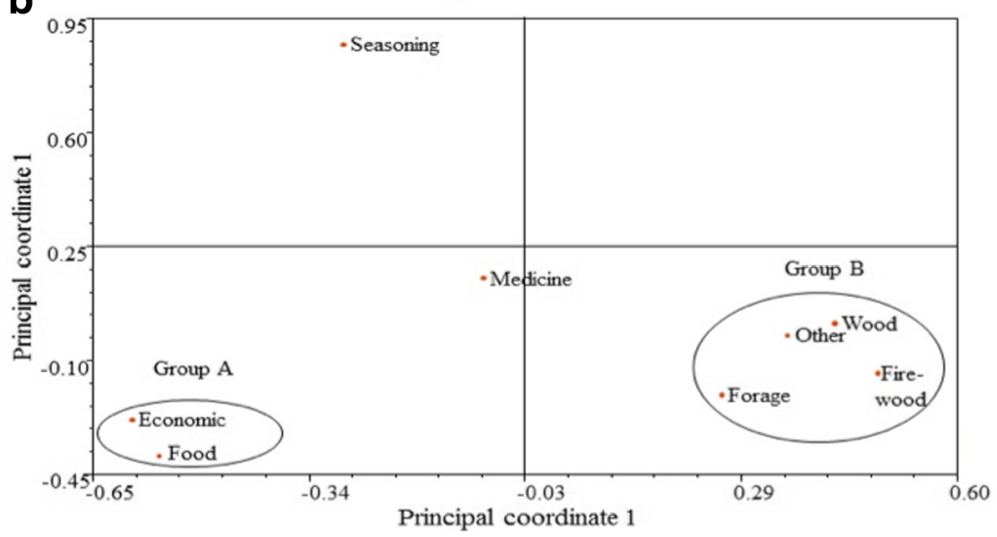

Fig. 3 Principal Coordinates Analysis (PCO) a per interviewed person in the community of Doche vereda (Villavieja, Huila) and b per ethnobotanical category. Names of the interviewed population correspond to a code and an interview number 
Table 2 Number of uses per ethnobotanical category and Richness of Knowledge Index (RQZ) of the useful flora by interviewed of the Doche vereda (Villavieja, Huila)

\begin{tabular}{|c|c|c|c|c|c|c|c|c|c|c|}
\hline Gender & Interviewed ${ }^{a}$ & Fo & $\mathrm{Co}$ & Ec & $\mathrm{Fd}$ & $\mathrm{Fi}$ & $\mathrm{Ti}$ & Me & Ot & RQZ index \\
\hline \multirow[t]{11}{*}{$\mathrm{F}$} & MI06 & 6 & 0 & 3 & 7 & 4 & 7 & 12 & 2 & 0.35 \\
\hline & IG16 & 7 & 1 & 4 & 7 & 7 & 2 & 15 & 1 & 0.35 \\
\hline & YB11 & 10 & 1 & 5 & 8 & 11 & 4 & 6 & 0 & 0.33 \\
\hline & OP07 & 6 & 1 & 3 & 8 & 7 & 3 & 6 & 1 & 0.27 \\
\hline & MV02 & 1 & 0 & 1 & 9 & 7 & 3 & 4 & 5 & 0.23 \\
\hline & AP14 & 2 & 0 & 2 & 6 & 7 & 4 & 5 & 4 & 0.23 \\
\hline & AM08 & 7 & 0 & 3 & 6 & 3 & 4 & 7 & 0 & 0.21 \\
\hline & LT04 & 0 & 0 & 0 & 6 & 4 & 5 & 6 & 2 & 0.18 \\
\hline & LC12 & 2 & 0 & 2 & 3 & 4 & 3 & 5 & 1 & 0.17 \\
\hline & AB09 & 3 & 0 & 3 & 4 & 5 & 2 & 2 & 0 & 0.16 \\
\hline & MR15 & 3 & 0 & 1 & 3 & 2 & 2 & 5 & 3 & 0.16 \\
\hline \multirow[t]{7}{*}{ M } & JT05 & 6 & 1 & 3 & 7 & 4 & 7 & 12 & 2 & 0.35 \\
\hline & JP10 & 3 & 1 & 3 & 7 & 11 & 10 & 7 & 0 & 0.25 \\
\hline & DA03 & 1 & 0 & 6 & 10 & 8 & 3 & 2 & 3 & 0.24 \\
\hline & DD17 & 4 & 1 & 7 & 6 & 7 & 2 & 6 & 0 & 0.24 \\
\hline & EB18 & 1 & 0 & 2 & 10 & 2 & 4 & 9 & 0 & 0.22 \\
\hline & RP13 & 2 & 0 & 2 & 8 & 8 & 2 & 6 & 2 & 0.21 \\
\hline & LA01 & 2 & 2 & 2 & 5 & 6 & 6 & 1 & 1 & 0.20 \\
\hline
\end{tabular}

${ }^{a}$ Name and interview number abbreviated by interviewed individual Ethnobotanical category: Fo food, Co condiment, Ec economy, Fd fodder, Fi firewood, Ti timber, Me medicine, Ot others

that reported for tropical dry forests of the Atlantic, Bolivar, Sucre, and Cesar [36, 43, 56]. This is explained by the subsistence needs of the Doche community, where cultivating species that guarantee certain services such as food, medicine, and fodder so that they are available yearlong is a priority.

When we analyzed by ethnobotanical category, we found 20 species within the timber category, which is less than what was reported in communities from the Complejo Ciénaga de Zapatosa and in Bailadores, Venezuela [34, 61], but similar to findings by Sanchez et al. [62], with 23 species of which only one (Maclura tinctoria) is cited in this work. The low availability of woody species resulting from the low rate at which this resource is produced in tropical dry forests, which is $50 \%$ slower than it is in tropical humid forests, has caused the substitution of these resources for cultivated species [63].

Quiroz-Carranza and Orellana [64] indicated the use of 41 species for firewood, which is more than we found in this study. The lower diversity of used species may be due to the preferences of inhabitants of the Doche community when selecting useful vegetation to use as firewood. The use of leucaena, guanabano, guacimo, and payandé is shared, since these species are easily grown in these dry ecosystems and have been reported to be preferred by peasant communities [65]. The recognition of firewoodbearing species can aid the preservation of tropical dry forests by pointing to strategies guaranteeing the availability of this resource and thus protect the species. The establishment of multiple use croplands close to the households [66], the extraction of dry timber from the forest in favor of woodcutting [64], and the design of stoves that increase the efficiency of firewood and keep spaces free of smoke are some of the suggested strategies to diminish the extraction of this resource from forests and allow its efficient use [67].

The fodder category grouped 28 species, more than what was reported by other studies [34, 35, 56, 68]. The number of species used as fodder in Doche is influenced by the cultivated plants and those collected from forests. Because of the climate conditions of the area, the community has implemented the cultivation of fodder species to avoid the displacement of cattle towards the higher areas of the forest. The use of guacimo [34], cuji [62], payandé, and leucaena [69] has been previously reported as fodder species. Additionally, according to studies of the nutritional value of these plants to rumiants, the use of matarratón, yuca, and leucaena coincides with this study [70].

The medicinal category was the most important in the Doche community. When comparing the number of medicinal species reported in previous research in tropical dry forests, we found that the Atlantic, Bolivar, and Cesar have a lower use of species $[35,56]$, as is the case in the peasant community of Santa Catalina de Chongoyape in Peru [71]. Differences in the number of medicinal species are associated to resource availability, species uses, and the significance a plant has in the community [72].

The main ailments treated with these plants in the study area are epidemiologically frequent diseases in warm zones [73]. For the treatment of illness, those interviewed considered twigs to be the most effective, which coincides with research showing they contain a relatively high concentration of active substances and secondary metabolites $[74,75]$, particularly in the bark [76]. Although it is well known that other portions of plants contain a much larger concentration of metabolites, the use of the twigs instead of that of floral organs and of fruits is due to the fact that these organs present a low availability of the resource throughout the year as an adaptation strategy to the tropical dry forest [77, 78]. The use of twigs for medicinal use has already been documented in previous 
studies by Carrillo-Rosario and Moreno [79], Giraldo et al. [80], and Jaramillo et al. [81].

The food category grouped 20 species, which is less than what has been reported in other studies in tropical dry forests [34-36]. The use of tropical dry forest edible species in Ecuador was equally low (13 species), while in Mexico, Martínez-Pérez et al. [82] reported 51 species, far surpassing than what was found in this study. The apparently small number of used species might be due to the fact that all plants in this category are cultivated. Considering the climate conditions of the area and the need for this resource among its inhabitants, the community is focused on cultivating a small number of species in crop fields.

Out of 20 food species, 13 are also included in the economy category. These are sold in Doche and the populated center Villavieja. The sale of vegetable species generates an income that allows communities to obtain other basic needs [33], as well as projecting programs for the sustainable use of ecosystems, and through it, preservation strategies generate [83]. Such was the case of two communities in the Chietla municipality in Puebla, Mexico, where socio-economic and ecological valuation of the useful flora was generated in order to establish conservation priorities [82].

On the other hand, when we compared the plants grouped in the others category, we did not find coincidences with flora reported in other studies. Despite this fact, the relevance of shadow plants is widely recognized, and their multiple use as timber and fodder is recognized [34, 35].

Meanwhile, the condiment category reported the lowest number of species: five. The community does not utilize diverse spices to season foods, and all condiment plants are cultivated. This is also reported in communities from the Perijá Mountains where two species are registered, of these, aji coincides with our findings [35]. In the tropical region of Cesar, Colombia, the same number of species is reported and the use of cilantro (Coriandrum sativum) and aji (Capsicum annuum) coincides with this study [34].

According to the results from the Pearson correlation test, a significant relationship was found between the number of uses per ethnobotanical category and cultural significance (see Appendix). Thus, species with the highest cultural significance will be those with the most different uses. To some authors, the frequency of being mentioned is a very effective indicator for the evaluation of cultural importance, mainly because it is a quick technique and relatively easy to carry out; however it does not say much about the particular importance of the different species [84]. On the other hand, literature points out that as long as a plant has more uses (food, medicine, fuel, or any other category), it will have greater importance [21, 22]. Different ethnobotanical studies have indicated that the sum of uses can be considered as an indicator that is directly related to the cultural importance of the plants and that the sum of uses can be a quick tool that provides quantitative data to evaluate this phenomenon [16]. Thus, based on the evidence, we can see how the number of uses of a plant is correlated with its degree of cultural importance. This allows us to recognize the relevance of these species and opens the possibility to generate management and preservation strategies in different ecosystems in future studies [85]. Additionally, it would be recommendable to use standardized ethnobotanical categories to compare between studies and study sites [86].

On the other hand, the Principal Coordinates Analysis per ethnobotanical category, showed the relationship between species and ethnobotanical categories. The first Principal Coordinate grouped species considered edible for the community that also provide families with income ("food" + "economy"; see Fig. 3b). Meanwhile, the second Principal Coordinate discriminated a greater number of categories, all of which share similar uses and are recognized by most of the interviewed population, such as timber species that can also be fodder for goats and sheep. According to this, a single species may be used in more than one category. This has been made reference to before in the study by Cárdenas and Ramírez [29]; however, to avoid bias in value allocation, it is recommended to cite the species once per category instead of according to each use given. This was done in this study according to proposals by Marín-Corba et al. [86] and Sánchez et al. [87].

The degree of knowledge of the useful species by collaborators in the Doche community, as measured through the Knowledge Richness Index, has no significant differences between genders. According to different authors, there are differences between men and women in knowledge about natural resources [27]. For Tuñon [88], the differences between the uses, access, and control that men and women have of their natural resources are evident. It can even be expected that women hold greater knowledge. To Sánchez-Núñez and Espinosa [89], women have a detailed knowledge about the natural environment that places them in a preponderant place in the administration of community natural resources. However, in the present study there seems to be no gender difference in the richness of knowledge. Although the level of plant knowledge varies, each person has a portion of the "total" knowledge and it can change according to necessities and priorities in 
each community as is concluded by Castellanos [23] in his study of the Cane river basin in Iguaque (Boyacá). Predominant economic activities, urbanization, individual roles, and cultural diversity are among the factors influencing how much communities know of their ecosystems and how they use them $[61,90]$.

Similarly, no significant differences were found between genders within ethnobotanical categories. Communities in greater contact with their ecosystems tend to relate the same species [85]. Differences in knowledge and perception of natural resources between men and women have been partially explained as a consequence of the sexual division of labor in traditional societies [27]. Nevertheless, in the Doche community, both men and women carry out similar activities, which can be evidenced in this study by their reporting the same useful species. This coincides with reports from Canales et al. [91] who indicated that the number of known plants is not related to the area they inhabit nor to gender, schooling, occupation, or place of origin, but rather to the role each person plays in a community and the activities they carry out in it. However, certain tendencies can be observed in some categories, for example, medicinal species are more readily recognized by women [26, 46], as are food species [92], while men have deeper knowledge of species used in construction and sold species [25]. Voeks and Leony [93] report that women from a rural community in the state of Bahia, Brazil, are significantly better informed than men about the names and medicinal properties of plants. Although our data did not support the hypothesis that there is a difference in the degree of knowledge between genders, within particular categories, such as medicinal plants, we found evidence that this difference does appear. According to the results of the $\mathrm{PCO}$ per category, a consensus was found in the information about useful plants, which would suggest homogeneity and preservation of traditional knowledge, contrasting with findings by Albuquerque et al. [13] and Lastres et al. [60], who cite traditional knowledge to be disperse among the people, which might lead to its eventual loss.

Finally, the relevance of culturally significant species has led to the recognition of resource availability and the knowledge communities have of plants [81, 94]. Additionally, strategies for a better use of ecosystems can be put into practice considering the most relevant species [34]. Cultural valuation should identify, recognize, and accept changes in preferences and the dynamic way in which communities learn, given that people are constantly modifying their ecosystems in search for optimal benefits [95]. This is evident in Doche, a community that has modified its agricultural and livestock-breeding practices to guarantee a longterm availability of the resources their environment provides. Furthermore, people in this community have received training to generate new strategies to utilize their ecosystems, as well as regulate the use or resources such as the wood that is extracted from the forest.

\section{Conclusions}

The usage strategies developed by people from Doche to thrive in their dry ecosystem lead us to the conclusion that knowledge of the cultural value of vegetable species is fundamental to endeavor in forest preservation without ceasing to use natural resources. The agreements on internal rules to control the extraction of timber and the cultivation of species for this purpose are strategies that this community have developed to preserve resources while still covering their basic needs. The establishment of cultivation crop lands, the limitation of livestock breeding within the forests, and the diversification of species has further contributed to the regeneration of the tropical dry forest.

The cultural valuation measured in the frequency of mention allowed us to recognize the cultural significance of species of the tropical dry forest; however, the importance of these species was explained by diverse factors such as the number of uses per ethnobotanical category, availability, and access to the resource. Furthermore, the recognition of ethnobotanical uses by gender showed that in the Doche community, men and women know the same species, both genders participate in agricultural endeavors, the collection of wood, herding, production of food, and selling, as well as group activities carried out in the community. This has led to a homogeneously distributed and well-preserved ethnobotanical knowledge.

The community is more invested in preserving species with a higher cultural significance because these provide them with basic resources for subsistence. Each person has a portion of the general knowledge, and this is modified according to immediate needs, as well as the availability and access to resources. Therein lies the relevance of recognizing useful species, use areas, and socio-ecological relationships between a population and its ecosystem. The knowledge of useful flora and its cultural valuation represents a relevant step towards the preservation of the tropical dry forest, one of the most fragmented ecosystems in Colombia. The participation of communities in the preservation of this ecosystem is fundamental for strategies to guarantee a long-term conservation of this ecosystem and the services with which it provides the population. 


\section{Appendix}

Table 3 Species used by the Doche commnity (Villavieja, Huila)

\begin{tabular}{|c|c|c|c|c|c|c|}
\hline Useful Flora & Common name & Zone & $\begin{array}{l}\text { Ethnobotanical } \\
\text { category }\end{array}$ & $\begin{array}{l}\text { Total } \\
\text { Uses }\end{array}$ & $\begin{array}{l}\text { Freq. of being } \\
\text { mentioned }\end{array}$ & $\begin{array}{l}\text { Relative freq. of } \\
\text { being mentioned }\end{array}$ \\
\hline \multicolumn{7}{|l|}{ Achariaceae } \\
\hline Carpotroche grandiflora Spruce ex Benth. & Achotillo & $\mathrm{F}$ & Ot & 1 & 2 & 0.11 \\
\hline Justicia pectoralis Jacq. & Amansa guapo & C & $\mathrm{Me}$ & 1 & 1 & 0.06 \\
\hline Trichanthera gigantea (Bonpl.) Nees & Cuchiyuyo & C & $\mathrm{Ti} ; \mathrm{Fi} ; \mathrm{Ff} ; \mathrm{Me}$ & 4 & 4 & 0.22 \\
\hline \multicolumn{7}{|l|}{ Amaranthaceae } \\
\hline Alternanthera sp. & Abreojo & $\mathrm{F} ; \mathrm{C}$ & $\mathrm{Me}$ & 1 & 5 & 0.28 \\
\hline \multicolumn{7}{|l|}{ Anacardiaceae } \\
\hline Anacardium occidentale L. & Marañón & C & Me & 1 & 1 & 0.06 \\
\hline Astronium graveolens Jacq. & Diomate & $\mathrm{F}$ & $\mathrm{Ti}$ & 1 & 4 & 0.22 \\
\hline Mangifera indica L. & Mango & C & Fo; Me & 2 & 2 & 0.11 \\
\hline Spondias sp. & Ciruelo & C & Me & 1 & 4 & 0.22 \\
\hline \multicolumn{7}{|l|}{ Annonaceae } \\
\hline Annona muricata $\mathrm{L}$. & Guanábano & C & $\mathrm{Fi} ; \mathrm{Fo} ; \mathrm{Me} ; \mathrm{Ot}$ & 4 & 3 & 0.17 \\
\hline Annona squamosa $\mathrm{L}$. & Anón & C & $\mathrm{Me}$ & 1 & 1 & 0.06 \\
\hline \multicolumn{7}{|l|}{ Apiaceae } \\
\hline Coriandrum sativum L. & Cilantro & C & $\mathrm{Co}$; Ec & 2 & 1 & 0.06 \\
\hline Eryngium foetidum $\mathrm{L}$. & Cilantro cimarrón & C & $\mathrm{Co} ; \mathrm{Me}$ & 2 & 3 & 0.17 \\
\hline \multicolumn{7}{|l|}{ Apocynaceae } \\
\hline Aspidosperma cuspa (Kunth) S.F. Blake ex Pittier & Amargoso & $\mathrm{F}$ & Ti; Fi; Fd & 3 & 10 & 0.56 \\
\hline \multicolumn{7}{|l|}{ Araceae } \\
\hline Xanthosoma sagittifolium (L.) Schott & Bore & C & $\mathrm{Fd}$ & 1 & 5 & 0.28 \\
\hline \multicolumn{7}{|l|}{ Arecaceae } \\
\hline Bactris gasipaes Kunth & Cachipay; Chontaduro & C & Fo & 1 & 1 & 0.06 \\
\hline Cocos nucifera L. & Coco & C & Fo & 1 & 1 & 0.06 \\
\hline \multicolumn{7}{|l|}{ Asphodeloideae } \\
\hline Aloe vera (L.) Burm. f. & Sábila & C & Me; Ec & 2 & 7 & 0.39 \\
\hline \multicolumn{7}{|l|}{ Asteraceae } \\
\hline Calendula sp. & Caléndula & C & $\mathrm{Me}$ & 1 & 1 & 0.06 \\
\hline Lactuca sativa $\mathrm{L}$. & Lechuga & C & Fo; Ec & 2 & 1 & 0.06 \\
\hline Pseudelephantopus spiralis (Less.) Cronquist & $\begin{array}{l}\text { Consuelda; yerbagole; } \\
\text { hierba golpe }\end{array}$ & C & $\mathrm{Fd} ; \mathrm{Me}$ & 2 & 2 & 0.11 \\
\hline Tridax procumbens $\mathrm{L}$. & Chisacá & C & $\mathrm{Me}$ & 1 & 8 & 0.44 \\
\hline \multicolumn{7}{|l|}{ Boraginaceae } \\
\hline Cordia dentata Poir. & Gomo & C & $\mathrm{Fi} ; \mathrm{Fd} ; \mathrm{Me} ; \mathrm{Ot}$ & 4 & 6 & 0.33 \\
\hline \multicolumn{7}{|l|}{ Bromeliaceae } \\
\hline Bromelia pinguin L. & Piñuela & $\mathrm{F}$ & Fo & 1 & 1 & 0.06 \\
\hline \multicolumn{7}{|l|}{ Burseraceae } \\
\hline Bursera graveolens (Kunth) Triana \& Planch. & Tatamaco & $\mathrm{F}$ & $\mathrm{Ti}$ & 3 & 5 & 0.28 \\
\hline Bursera tomentosa (Jacq.) Triana \& Planch. & Zazafra; sasafrás & $\mathrm{F}$ & $\mathrm{Ti} ; \mathrm{Fi} ; \mathrm{Me}$ & 1 & 2 & 0.11 \\
\hline \multicolumn{7}{|l|}{ Cactaceae } \\
\hline Melocactus curvispinus Pfeiff. & Cabeza de negro & $\mathrm{F}$ & Fo & 1 & 3 & 0.17 \\
\hline Stenocereus griseus (Haw.) Buxb. & Cardo & $\mathrm{F}$ & $\mathrm{Fi} ; \mathrm{Fd}$ & 2 & 9 & 0.50 \\
\hline
\end{tabular}


Table 3 Species used by the Doche commnity (Villavieja, Huila) (Continued)

\begin{tabular}{|c|c|c|c|c|c|c|}
\hline Useful Flora & Common name & Zone & $\begin{array}{l}\text { Ethnobotanical } \\
\text { category }\end{array}$ & $\begin{array}{l}\text { Total } \\
\text { Uses }\end{array}$ & $\begin{array}{l}\text { Freq. of being } \\
\text { mentioned }\end{array}$ & $\begin{array}{l}\text { Relative freq. of } \\
\text { being mentioned }\end{array}$ \\
\hline \multicolumn{7}{|l|}{ Caricaceae } \\
\hline Carica papaya L. & Papaya & C & Fo; Me & 2 & 4 & 0.22 \\
\hline \multicolumn{7}{|l|}{ Convolvulaceae } \\
\hline Ipomoea sp. & Calambrino & $\mathrm{F}$ & $\mathrm{Fd}$ & 1 & 1 & 0.06 \\
\hline \multicolumn{7}{|l|}{ Cucurbitaceae } \\
\hline Momordica charantia L. & Simecojé & C & Me & 1 & 1 & 0.06 \\
\hline \multicolumn{7}{|l|}{ Euphorbiaceae } \\
\hline Cnidoscolus urens (L.) Arthur & Pringamosa & $\mathrm{F}$ & $\mathrm{Me}$ & 1 & 5 & 0.28 \\
\hline Croton pedicellatus Kunth & Sanca de arriero; Mosquero & $\mathrm{F}$ & $\mathrm{Fd} ; \mathrm{Me}$; Ot & 3 & 9 & 0.50 \\
\hline Jatropha curcas L. & Piñón & C & Me & 1 & 1 & 0.06 \\
\hline Manihot esculenta Crantz & Yuca & C & Fd; Fo; Ot & 3 & 16 & 0.89 \\
\hline Pedilanthus tithymaloides (L.) Poit. & $S / N$ & $\mathrm{~F}$ & $\mathrm{Fd}$ & 1 & 1 & 0.06 \\
\hline \multicolumn{7}{|l|}{ Lamiaceae } \\
\hline Melissa officinalis L. & Toronjil & C & Me & 1 & 2 & 0.11 \\
\hline Mentha spicata L. & Yerbabuena & C & $\mathrm{Co} ; \mathrm{Me}$ & 2 & 9 & 0.50 \\
\hline Ocimum basilicum L. & Albahaca & C & $\mathrm{Me}$ & 1 & 2 & 0.11 \\
\hline Origanum vulgare $\mathrm{L}$. & Orégano & C & $\mathrm{Co} ; \mathrm{Me}$ & 2 & 5 & 0.28 \\
\hline Thymus sp. & Tomillo & C & Me & 1 & 2 & 0.11 \\
\hline \multicolumn{7}{|l|}{ Lauraceae } \\
\hline Persea americana Mill. & Aguacate & C & Fo; Me & 2 & 1 & 0.06 \\
\hline \multicolumn{7}{|l|}{ Fabaceae } \\
\hline Acacia farnesiana (L.) Willd. & Pelá & $\mathrm{F}$ & $\mathrm{Fi} ; \mathrm{Fd} ; \mathrm{Me}$ & 3 & 15 & 0.83 \\
\hline Acacia sp. & Ambuco & $\mathrm{F}$ & $\mathrm{Ti} ; \mathrm{Fi} ; \mathrm{Fd}$ & 3 & 10 & 0.56 \\
\hline Desmanthus virgatus (L.) Willd. & Desinchadera & $\mathrm{F} ; \mathrm{C}$ & $\mathrm{Fd} ; \mathrm{Me}$ & 2 & 6 & 0.33 \\
\hline Erythrina fusca Lour. & Cachimbo & C & $\mathrm{Ti} ; \mathrm{Fi}$ & 2 & 2 & 0.11 \\
\hline Gliricidia sepium (Jacq.) Kunth ex Walp. & Matarratón & C & Ti; Fi; Fd; Me; Ot & 5 & 13 & 0.72 \\
\hline Hymenaea courbaril L. & Algarrobo & $\mathrm{F} ; \mathrm{C}$ & $\mathrm{Fi} ; \mathrm{Fd} ; \mathrm{Ot}$ & 3 & 6 & 0.33 \\
\hline Leucaena leucocephala (Lam.) de Wit & Leucaena & C & Ti; Fi; Fo & 3 & 10 & 0.56 \\
\hline Machaerium sp. & Siete Cueros & $\mathrm{F}$ & $\mathrm{Fi}$ & 1 & 1 & 0.06 \\
\hline Parkinsonia aculeata L. & Retamo & $\mathrm{F}$ & $\mathrm{Fd}$ & 1 & 1 & 0.06 \\
\hline Pithecellobium sp. & Mulato & $\mathrm{F}$ & $\mathrm{Ti} ; \mathrm{Fi}$ & 2 & 2 & 0.11 \\
\hline Pithecellobium dulce (Roxb.) Benth. & Payandé & $\mathrm{F}$ & $\mathrm{Ti} ; \mathrm{Fi} ; \mathrm{Fd}$ & 3 & 15 & 0.83 \\
\hline Prosopis juliflora & Cuji & $\mathrm{F}$ & $\mathrm{Fi} ; \mathrm{Fd} ; \mathrm{Ot}$ & 3 & 9 & 0.50 \\
\hline Pseudosamanea guachapele (Kunth) Harms & Iguá & $\mathrm{F} ; \mathrm{C}$ & $\mathrm{Ti} ; \mathrm{Fi}$ & 2 & 18 & 1.00 \\
\hline Senna sp. & Chilinchil & $\mathrm{F}$ & $\mathrm{Fi} ; \mathrm{Ot}$ & 2 & 2 & 0.11 \\
\hline Tamarindus indica $\mathrm{L}$. & Tamarindo & C & Fo & 1 & 1 & 0.06 \\
\hline \multicolumn{7}{|l|}{ Loranthaceae } \\
\hline Oryctanthus sp. & Pajarito & $\mathrm{F} ; \mathrm{C}$ & $\mathrm{Fd}$ & 1 & 2 & 0,11 \\
\hline \multicolumn{7}{|l|}{ Malvaceae } \\
\hline Gossypium sp. & Algodón & C & Ec & 1 & 1 & 0.06 \\
\hline Guazuma ulmifolia Lam. & Guácimo & $\mathrm{F} ; \mathrm{C}$ & $\mathrm{Ti} ; \mathrm{Fi} ; \mathrm{Fd} ; \mathrm{Me} ; \mathrm{Ec}$ & 5 & 17 & 0.94 \\
\hline Heliocarpus americanus L. & Balso & $\mathrm{F} ; \mathrm{C}$ & $\mathrm{Fi}$ & 1 & 1 & 0.06 \\
\hline Sida rhombifolia L. & Escoba & $C$ & Me; Ot & 2 & 2 & 0.11 \\
\hline
\end{tabular}


Table 3 Species used by the Doche commnity (Villavieja, Huila) (Continued)

\begin{tabular}{|c|c|c|c|c|c|c|}
\hline Useful Flora & Common name & Zone & $\begin{array}{l}\text { Ethnobotanical } \\
\text { category }\end{array}$ & $\begin{array}{l}\text { Total } \\
\text { Uses }\end{array}$ & $\begin{array}{l}\text { Freq. of being } \\
\text { mentioned }\end{array}$ & $\begin{array}{l}\text { Relative freq. of } \\
\text { being mentioned }\end{array}$ \\
\hline Theobroma cacao L. & Cacao & C & $\mathrm{Fi} ; \mathrm{Fo} ; \mathrm{Me} ; \mathrm{Ec}$ & 4 & 12 & 0.67 \\
\hline \multicolumn{7}{|l|}{ Meliaceae } \\
\hline Azadirachta indica A. Juss. & $\mathrm{Nim}$ & C & Ot & 1 & 1 & 0.06 \\
\hline Cedrela odorata $\mathrm{L}$. & Cedro & $\mathrm{F}$ & $\mathrm{Ti}$ & 1 & 4 & 0.22 \\
\hline Guarea guidonia (L.) Sleumer & Bili bil & C & $\mathrm{Ti}$ & 1 & 6 & 0.33 \\
\hline Trichilia appendiculata (Triana \& Planch.) C. DC. & Yayo & $\mathrm{F}$ & $\mathrm{Ti}$ & 1 & 3 & 0.17 \\
\hline Trichilia sp. & Coyo & $\mathrm{F}$ & $\mathrm{Ti}$ & 1 & 4 & 0.22 \\
\hline \multicolumn{7}{|l|}{ Moraceae } \\
\hline Artocarpus altilis (Parkinson) Fosberg & Juan Pana & C & $\mathrm{Fd} ; \mathrm{Fo}$ & 2 & 2 & 0.11 \\
\hline Maclura tinctoria (L.) D. Don ex Steud. & Dinde & $\mathrm{F}$ & Ti: Fd & 2 & 9 & 0.50 \\
\hline \multicolumn{7}{|l|}{ Moringaceae } \\
\hline Moringa oleífera Lam. & Moringa & C & $\mathrm{Fd} ; \mathrm{Me} ; \mathrm{Ot}$ & 3 & 3 & 0.17 \\
\hline \multicolumn{7}{|l|}{ Muntingiaceae } \\
\hline Muntingia calabura $\mathrm{L}$. & Chicható & $\mathrm{F} ; \mathrm{C}$ & $\mathrm{Fi} ; \mathrm{Fo} ; \mathrm{Ot}$ & 3 & 3 & 0.17 \\
\hline \multicolumn{7}{|l|}{ Musaceae } \\
\hline Musa balbisiana Colla & Plátano & C & Fo; Al; Ot & 3 & 16 & 0.89 \\
\hline \multicolumn{7}{|l|}{ Myrtaceae } \\
\hline Myrcia sp. & Arrayán & $\mathrm{F}$ & $\mathrm{Ti}$ & 1 & 1 & 0.06 \\
\hline Psidium guajava $\mathrm{L}$. & Guayaba & C & Fo & 1 & 1 & 0.06 \\
\hline Psidium guineense Sw. & Guayaba cimarrón & $\mathrm{F}$ & Me & 1 & 1 & 0.06 \\
\hline \multicolumn{7}{|l|}{ Phytolaccaceae } \\
\hline Petiveria alliacea $\mathrm{L}$. & Anamú & C & Me & 1 & 3 & 0.17 \\
\hline \multicolumn{7}{|l|}{ Poaceae } \\
\hline Brachiaria decumbens Stapf & Pasto & C & $\mathrm{Fd}$; Ec & 2 & 13 & 0.72 \\
\hline Cymbopogon citratus (DC.) Stapf & Limoncillo & C & Me & 1 & 6 & 0.33 \\
\hline Guadua angustifolia Kunth & Guadua & C & $\mathrm{Fi} ; \mathrm{Ot}$ & 2 & 8 & 0.44 \\
\hline Gynerium sagittatum (Aubl.) P. Beauv. & Pinto; pindo & C & $\mathrm{Fd} ; \mathrm{Ot}$ & 2 & 3 & 0.17 \\
\hline Oryza sativa $\mathrm{L}$. & Arroz & C & Fo; Ec & 2 & 3 & 0.17 \\
\hline Saccharum officinarum L. & Caña & C & Fi; Fo & 2 & 4 & 0.22 \\
\hline Sorghum bicolor (L.) Moench & Sorgo & C & Ec & 1 & 1 & 0.06 \\
\hline Zea mays $\mathrm{L}$. & Maíz & C & Fd; Fo; Ec & 3 & 8 & 0.44 \\
\hline \multicolumn{7}{|l|}{ Portulacaceae } \\
\hline Portulaca sp. & Verdolaga & $\mathrm{F}$ & Me & 1 & 3 & 0.17 \\
\hline \multicolumn{7}{|l|}{ Rubiaceae } \\
\hline Machaonia acuminata Bonpl. & Cacho de venado & $\mathrm{F}$ & $\mathrm{Fi}$ & 1 & 5 & 0.28 \\
\hline Randia aculeata L. & Cruceto & $\mathrm{F}$ & $\mathrm{Fi} ; \mathrm{Ot}$ & 2 & 3 & 0.17 \\
\hline \multicolumn{7}{|l|}{ Rutaceae } \\
\hline Amyris pinnata Kunth & Milanda & $\mathrm{F}$ & $\mathrm{Ti}$ & 1 & 1 & 0.06 \\
\hline Citrus $\times$ sinensis (L.) Osbeck & Naranjo & C & Fo; Me & 2 & 2 & 0.11 \\
\hline Citrus × limón (L.) Osbeck & Limón & C & Fo; Me; Ec & 3 & 6 & 0.33 \\
\hline Zanthoxylum sp. & Tachuelo & $\mathrm{F}$ & $\mathrm{Fi}$ & 1 & 1 & 0.06 \\
\hline \multicolumn{7}{|l|}{ Salicaceae } \\
\hline Casearia tremula (Griseb.) Griseb. ex C. Wright & Varazón & $\mathrm{F}$ & $\mathrm{Fi}$ & 1 & 1 & 0.06 \\
\hline
\end{tabular}


Table 3 Species used by the Doche commnity (Villavieja, Huila) (Continued)

\begin{tabular}{|c|c|c|c|c|c|c|}
\hline Useful Flora & Common name & Zone & $\begin{array}{l}\text { Ethnobotanical } \\
\text { category }\end{array}$ & $\begin{array}{l}\text { Total } \\
\text { Uses }\end{array}$ & $\begin{array}{l}\text { Freq. of being } \\
\text { mentioned }\end{array}$ & $\begin{array}{l}\text { Relative freq. of } \\
\text { being mentioned }\end{array}$ \\
\hline Sideroxylon celastrinum (Kunth) T.D. Penn. & Chisposo & $\mathrm{F}$ & $\mathrm{Fd}$ & 1 & 1 & 0.06 \\
\hline \multicolumn{7}{|l|}{ Solanaceae } \\
\hline Capsicum annuum L. & Aji & P & Co & 1 & 2 & 0.11 \\
\hline \multicolumn{7}{|l|}{ Verbenaceae } \\
\hline Lippia alba (Mill.) N.E. Br. ex Britton \& P. Wilson & Pronto alivio & C & Me & 1 & 3 & 0.17 \\
\hline Verbena litoralis Kunth & Verbena & C & $\mathrm{Me}$ & 1 & 1 & 0.06 \\
\hline \multicolumn{7}{|l|}{ Not identified } \\
\hline Sp 1. & Encaje & C & $\mathrm{Me}$ & 1 & 2 & 0.11 \\
\hline Sp 2. & Hita moreal & C & Me & 1 & 1 & 0.06 \\
\hline Sp 3. & Insulina & $C$ & $\mathrm{Me}$ & 1 & 1 & 0.06 \\
\hline Sp 4. & Yuquillo & $\mathrm{F}$ & Me & 1 & 1 & 0.06 \\
\hline
\end{tabular}

Species use zone: $C$ cropland, $F$ forest. Ethnobotanical category: Fo food, Co condiment, Ec economy, Fd fodder, Fi firewood, $T i$ timber, $M e$ medicine, Ot others, S/N no common name

\section{Abbreviations}

Ar: Aromatic; Ba: Bark; Bt: Baths; C: Cropland; Co: Condiment; De: Decoration; Ec: Economy; Ex: External; F: Forest; FA: Form of application; Fd: Fodder;

Fi: Firewood; Fl: Flower; Fo: Food; FP: Form of preparation; Fr: Fruit; Ju: Juice; Le: Leaf; Me: Medicine; N/I: Not identified; NP: No preparation; Or: Oral; Ot: Others; PCO: Principal Coordinates Analysis; Po: Poultice; Ro: Root; RQZ: Knowledge Richness Index; S/N: No common name; St: Stalk; Ti: Timber; To: Topical; Tw: Twig

\section{Acknowledgements}

We sincerely thank all residents of Doche vereda for their hospitality and disposition to collaborate in this study. Finally, we thank Marisa Ordaz for translating this manuscript to English.

\section{Funding}

This study was funded by the COLCIENCIAS Program: "Formación de capital humano de alto nivel para el departamento del Huila", Colombia.

\section{Availability of data and materials}

We have already included all data in the manuscript collected during the field surveys.

\section{Authors' contributions}

JRT wrote early drafts of the research design and the manuscript and did the fieldwork. DSF and LRD reviewed and improved the proposal and the manuscript. Finally, FRS participated in the "Discussion" section and reviewed the manuscript. All authors read and approved the final manuscript.

\section{Ethics approval and consent to participate}

We obtained permission from each informant before conducting the interview. All the participants were anonymized and so their personal details are not disclosed in this paper.

\section{Consent for publication}

$$
\text { Not applicable. }
$$

\section{Competing interests}

The authors declare that they have no competing interests.

\section{Publisher's Note}

Springer Nature remains neutral with regard to jurisdictional claims in published maps and institutional affiliations.

\section{Author details}

'Universidad de Ciencias Aplicadas y Ambientales, 222 St. 55-37, E-111166 Bogotá, Colombia. ${ }^{2}$ Asociación Etnobiológica Mexicana A.C., Calle Profesor
Felipe W. Mijangos, Colonia 12 de Junio, E-29243 San Cristóbal de Las Casas, Chiapas, Mexico. ${ }^{3}$ Centro de Investigaciones Multidisciplinarias sobre Chiapas y la Frontera Sur, UNAM, Calle María Adelina Flores 34-A, Barrio Guadalupe, CP 29230 San Cristóbal de Las Casas, Chiapas, Mexico.

Received: 7 October 2017 Accepted: 8 March 2018

Published online: 22 March 2018

\section{References}

1. Costanza R, Farber S. Introduction to the special issue on the dynamics and value of ecosystem services: integrating economic and ecological perspectives. Ecol Econom. 2002; https://doi.org/10.1016/S09218009(02)00087-3.

2. Cowling RM, Egoh B, Knight AT, O'Farrell PJ, Reyers B, Rouget M, et al. An operational model for mainstreaming ecosystem services for implementation. Proc Natl Acad Sci U S A. 2008; https://doi.org/10.1073/ pnas.0706559105.

3. De Groot RS, Wilson MA, Boumans RMJ. A typology for the classification, description and valuation of ecosystem functions, goods and services. Ecol Econom. 2002; https://doi.org/10.1016/50921-8009(02)00089-7.

4. Laterra P, Castellarini F, Orúe ME. ECOSER: Un protocolo para la evaluación biofísica de servicios ecosistémicos y la integración con su valor social. In: Laterra P, Jobbágy EG, Paruelo JM, editors. Valoración de Servicios Ecosistémicos: conceptos, herramientas y aplicaciones para el ordenamiento territorial. Buenos Aires: Instituto Nacional de Tecnología Agropecuaria; 2011. p. 359-89.

5. Bennett EM, Cramer W, Begossi A, Cundill G, Díaz S, Egoh BN, et al. Linking biodiversity, ecosystem services, and human well-being: three challenges for designing research for sustainability. Curr Opin Environ Sustain. 2015; https://doi.org/10.1016/j.cosust.2015.03.007.

6. Briceño J, Iniguez-Gallardo V, Ravera F. Factores que influyen en la apreciación de servicios ecosistémicos de los bosques secos del sur del Ecuador. Revista Ecosistemas. 2016; https:/doi.org/10.7818/ECOS.2016.25-2.06.

7. García del Valle YG, Naranjo EJ, Caballero J, Martorell C, Ruan-Soto F, Enríquez PL. Cultural significance of wild mammals in mayan and mestizo communities of the Lacandon Rainforest, Chiapas, Mexico. J Ethnobiol Ethnomed. 2015; https://doi.org/10.1186/s13002-015-0021-7.

8. Hunn ES. The utilitarian factor in flog biological classification. Am Anthropol. 1982:4:830-47.

9. González-Insuasti MS, Caballero J. Managing plant resources: how intensive can it be? Hum Ecol. 2007;35:303-14.

10. Bravo-Avilés D. Relación entre la importancia cultural y atributos ecológicos en tres especies de cactáceas en la mixteca poblana. Tesis de Maestría. Universidad Autónoma Metropolitana, Iztapalapa, Mexico. 2011. http://148. 206.53.84/tesiuami/UAM115438.pdf 
11. Vilardy SP, González JA, Martín-López B, Oteros-Rozas E. Los servicios de los ecosistemas de la Reserva de Biosfera Ciénaga Grande de Santa Marta. Revista Iberoamericana de Economía Ecológica. 2012;19:66-83.

12. Infante-Ramírez KD, Arce-lbarra AM. Percepción local de los servicios ecológicos y de bienestar de la selva de la zona maya en Quintana Roo, México. Boletín del Instituto de Geografía. 2015;86:67-81.

13. Albuquerque UP, Lucena RFP, Monteiro JM, Florentino ATN, Almeida CFCBR. Evaluating two quantitative ethnobotanical techniques. Ethnobot Res Appl. 2006;4:51-60.

14. Tardío J, Pardo-de-Santayana M. Cultural importance indices: a comparative analysis based on the useful wild plants of Southern Cantabria (Northern Spain). Econ Bot. 2008;62:24-39.

15. Weller SC, Romney AK. Systematic data collection, vol. 10. Newbury Park: Sage publications; 1988.

16. Phillips OL, Gentry AH. The useful plants of Tambopata Peru: I: statistical hypotheses tests with a new quantitative technique. Econ Bot. 1993;47:15-32

17. MDLA LT, Islebe GA. Traditional ecological knowledge and use of vegetation in southeastern Mexico: a case study from Solferino, Quintana Roo. Biodivers Conserv. 2003;12:2455-76.

18. Lucena RFP, Lima Araújo E, Albuquerque UP. Does the local availability of woody Caatinga plants (Northeastern Brazil) explain their use value? Econ Bot. 2007;61:347-61

19. González-Insuasti MS, Martorell C, Caballero J. Factors that influence the intensity of non-agricultural management of plant resources. Agrofor Syst. 2008;74:1-15.

20. Casas A, Caballero J. Traditional management and morphological variation in Leucaena esculenta (Fabaceae: Mimosoideae) in the Mixtec Region of Guerrero, Mexico. Econ Bot. 1996:50:167-81.

21. Turner NJ. The importance of a rose: evaluating the cultural significance of plants in Thompson and Lillooet Interior Salish. Am Anthropol. 1988:90:272-90.

22. Phillips OL. Some quantitative methods for analysing ethnobotanical knowledge. In: Alexiades MN, editor. Selected quidelines for ethnobotanical research: a field manual. New York: The New York Botanical Garden; 1996. p. 171-97.

23. Castellanos LI. Conocimiento etnobotánico, patrones de uso y manejo de plantas útiles en la cuenca del río Cane-lguaque (Boyacá-Colombia): una aproximación desde los sistemas de uso de la biodiversidad. Ambiente Sociedade. 2011;14:45-75.

24. Medellín SG, Barrientos L, del Amo Rodríguez S, Almaguer P, Mora SG. Uso de la flora tradicional de la Reserva de la Biosfera El Cielo. Tamaulipas Investigación y Ciencia. 2016;24:32-8.

25. León M, Cueva P, Aguirre Z, Kvist L. Composición florística, estructura, endemismo y etnobotánica del bosque nativo "El Colorado", en el cantón Puyango, provincia de Loja. Lyonia. 2006;10:105-15.

26. Vázquez B, Martínez B, Aliphat MM, Aguilar A. Uso y conocimiento de plantas medicinales por hombres y mujeres en dos localidades indígenas en Coyomeapan, Puebla, México. Interciencia. 2011;36:493-9.

27. Camou A, Reyes-García V, Martínez-Ramos M, Casas A. Knowledge and use value of plant species in a Rarámuri community: a gender perspective for conservation. Hum Ecol. 2007; https://doi.org/10.1007/s10745-007-9152-3.

28. Velázquez-Gutiérrez M. Hacia la construcción de la sustentabilidad social: ambiente, relaciones de género y unidades domésticas. In: Tuñón E, editor. Género y Medio ambiente. Mexico: Ecosur-SemarnatPlaza y Valdés; 2003. p. 79-106.

29. Cárdenas D, Ramírez-A JG. Plantas útiles y su incorporación a los sistemas productivos del departamento del Guaviare (Amazonía Colombiana). Caldasia. 2004;26:95-110

30. Pino $\mathrm{N}$, Valois $\mathrm{H}$. Ethnobotany of four black communities of the municipality of Quibdó, Chocó-Colombia. Lyonia. 2004;7:59-68.

31. Estupiñán-González AC, Jiménez-Escobar ND. Uso de las plantas por grupos campesinos en la franja tropical del Parque Nacional Natural Paramillo (Córdoba, Colombia). Caldasia. 2010;32:21-38.

32. Jiménez-Escobar ND, Albuquerque UP, Rangel-Ch JO. Huertos familiares en la bahía de Cispatá, Córdoba, Colombia. Bonplandia. 2011;20:309-28.

33. Zuluaga GP, Ramírez LA. Uso, manejo y conservación de la agrobiodiversidad por comunidades campesinas afrocolombianas en el municipio de Nuquí, Colombia. Etnobiología. 2015:13:5-18.

34. Cruz MP, Estupiñán AC, Jiménez-Escobar ND, Sánchez N, Galeano G, Linares E. Etnobotánica de la región tropical del Cesar, Complejo Ciénaga de Zapatosa. In: Rangel-Ch JO, editor. Colombia diversidad Biótica VIII: media y baja montaña de la serranía de Perijá. Bogotá: Universidad Nacional de Colombia; 2009. p. 417-47.
35. Jiménez-Escobar ND, Estupiñán-González AC, Sánchez N, Garzón C. Etnobotánica de la media montaña de la Serranía del Perijá. In: Rangel-Ch JO, editor. Colombia diversidad biótica, media y baja montaña de la serranía del Perijá. Bogotá: Universidad Nacional de Colombia, Instituto de Ciencias Naturales, CORPOCESAR-REVIVE; 2009. p. 393-416.

36. Barrios-Paternina E, Mercado-Gómez J. Plantas útiles del corregimiento Santa Inés y la vereda San Felipe (San Marcos, Sucre, Colombia). Revista Ciencia en Desarrollo. 2014;5:131-44.

37. Carvajal LM, Turbay S, Álvarez LM, Rodríguez A, Álvarez M, Bonilla K, Restrepo S, Parra M. Propiedades funcionales y nutricionales de seis especies de pasifloras del departamento del Huila. Caldasia. 2014;36:1-15.

38. Fajardo SV. Estudio etnobotánico para la identificación del recurso forestal no maderable con mayor potencial medicinal y comercial en la cuenca media y baja del río Las Ceibas en Neiva, Colombia. Entornos. 2015;27:13-25.

39. Romero-Duque L, Batista-Morales MF, Vargas JA, Jaramillo VJ, Balvanera P, Mocaleano AM. Diversidad y servicios ecosistémicos del Bosque Tropical seco de la cuenca Alta del río Magdalena. Bogotá: Universidad de Ciencias Aplicadas y Ambientales; 2016.

40. Fandiño M, Wyngaarden W. Zonificación para el manejo del Parque Natural Regional de la Tatacoa. Informe Final de los convenios 300 y 279 de 2009. Neiva: Grupo ARCO; 2010.

41. Sánchez-Azofeifa GA, Quesada M, Rodríguez JP, Nassar JM, Stoner KE, Castillo A, et al. Research priorities for Neotropical dry forests. Biotropica. 2005;37:477-85

42. Plan de desarrollo de Villavieja 2012-2015. Villavieja jUnidos por el cambio!; 2012. http://www.villavieja-huila.gov.co/Nuestros_planes.shtml?apc=gbxx-1$\& x=2629980$.

43. Guber R. La etnografía: método, campo y reflexividad. Bogotá: Grupo editorial Norma; 2001

44. Heinrich M, Ankli A, Frei B, Weimann C, Sticher O. Medicinal plants in Mexico: healers' consensus and cultural importance. Soc Sci Med. 1998;47: 1859-71.

45. Montoya EA. Aprovechamiento de los hongos silvestres comestibles en el volcán la Malinche, Tlaxcala. Tesis de Doctorado. Posgrado en ciencias biológicas, Facultad de ciencias. Universidad Nacional Autónoma de México, Mexico; 2005. http://www.remeri.org.mx/portal/REMERI.jsp?id=oai:tesis. dgbiblio.unam.mx:000345191

46. Hernández T, Canales M, Caballero J, Durán Á, Lira R. Análisis cuantitativo del conocimiento tradicional sobre plantas utilizadas para el tratamiento de enfermedades gastrointestinales en Zapotitlán de las Salinas, Puebla, México. Interciencia. 2005:30:529-35.

47. Agelet A, Vallés J. Studies on pharmaceutical ethnobotany in the region of Pallars (Pyrenees, Catalonia, Iberian Peninsula). Part I. General results and new or very rare medicinal plants. J Ethnopharmacol. 2001; https://doi.org/ 10.1016/S0378-8741(01)00262-8.

48. Burrola-Aguilar C, Montiel O, Garibay-Orijel R, Zizumbo-Villarreal L. Conocimiento tradicional y aprovechamiento de los hongos comestibles silvestres en la región de Amanalco, Estado de México. Revista mexicana de micología. 2012:35:1-16.

49. Zar JH. Biostatistical analysis. 2nd ed. New Jersey: Prentice Hall; 1984.

50. Rohlf FJ. NTSYS-pc numerical taxonomy and multivariate analysis system. v. 2.01. Setauket New York: applied. Biostatistics. 2000;

51. Geilfus F. 80 herramientas para el desarrollo participativo. San José, Costa Rica: Instituto Interamericano de Cooperación para la. Agricultura. 2002;

52. Figueroa $Y$, Galeano G. Lista comentada de las plantas vasculares del enclave seco interandino de La Tatacoa (Huila, Colombia). Caldasia. 2007;29: 263-81.

53. Llanos F. Flora del desierto de la Tatacoa Municipio de Villavieja (Huila) Colombia. Neiva: Universidad Surcolombiana; 2010

54. Olaya A, Gutiérrez GA, editors. La Tribuna, reserva natural en zona petrolera del norte del Huila. 1rd ed. Neiva: Grupo de Investigación Ecosistemas Surcolombianos (ECOSURC), Universidad Surcolombiana; 2014.

55. Mendoza-C H. Estructura y riqueza florística del bosque seco tropical en la región Caribe y el valle del río Magdalena, Colombia. Caldasia 1999:21:70-94.

56. Rodríguez G, Banda-R K, Reyes SP, Estupiñan A. Lista comentada de las plantas vasculares de bosques secos prioritarios para la conservación en los departamentos de Atlántico y Bolívar (Caribe colombiano). Biota Colombiana. 2012:13:7-39.

57. Fajardo L, Gonzales V, Nassar J, Lacabana P, Portillo CA, Carrasquel F, et al. Tropical dry forests of Venezuela: characterization and current conservation status. Biotropica. 2005;37:531-46. 
58. Albesiano S, Rangel-Ch JO. Estructura del cañón del río Chicamocha, 5001200m; Satander-Colombia: Una herramienta para la conservación. Caldasia. 2006;28:307-25.

59. Laterra-Álcazar DM, López RP, Barrientos D. The nurse-plant effect of propopis flexuosa D. C. (Leg-Mim) in a dry valley of the Bolivian Andes. Ecotropicos. 2005;18:89-95.

60. Lastres M, Ruiz-Zapata T, Castro M, Torrecilla P, Lapp M, Hernández-Chong L, et al. Conocimiento y uso de las plantas medicinales de la comunidad Valle de la Cruz, estado Aragua. Pittieria. 2015;39:59-89.

61. Aranguren A. Plantas útiles empleadas por los campesinos de la región de Bailadores. Venezuela Boletín Antropológico. 2005;23:139-65.

62. Sánchez $O$, Kvist LP, Aguirre Z. Bosques secos en Ecuador y sus plantas útiles. In: Moraes-RM, Øllgaard B, Kvist LP, Borchsenius F, Balslev H, editors. Botánica económica de los Andes Centrales. Bolivia: Universidad Mayor de San Andrés; 2006. p. 188-204

63. Valencia-Duarte J, Trujillo Ortiz LN, Vargas RO. Dinámica de la vegetación en un enclave semiárido del río Chicamocha, Colombia. Biota Colombiana. 2012;3:40-65.

64. Quiroz-Carranza J, Orellana R. Uso y manejo de leña combustible en viviendas de seis localidades de Yucatán, México. Madera y bosques. 2010; 16:47-67.

65. Couttolenc-Brenis E, Cruz-Rodríguez JA, Cedillo E, Musálem MA. Uso local y potencial de las especies arbóreas en camarón de Tejeda, Veracruz. Revista Chapingo. Serie ciencias forestales y del ambiente. 2005;11:445-50.

66. May T. Plantas preferidas para leña en la zona de bosque seco de Pedro Santana y Bánica, República Dominicana. Ambiente y Desarrollo. 2013;17:71-85.

67. Boy E, Bruce N, Smith KR, Hernandez R. Fuel efficiency of an improved wood-burning stove in rural Guatemala: implications for health, environment and development. Energy for sustainable development. 2000; 4:23-31.

68. Zamora P, Flores JS, Ruenes R. Flora útil y su manejo en el cono sur del estado de Yucatán. México Polibotánica. 2009;28:227-50.

69. Flores JS, Bautista F. Knowledge of the Yucatec Maya in seasonal tropical forest management: the forage plants. Revista Mexicana de Biodiversidad. 2012;83:503-18.

70. Cáceres $\mathrm{O}$, González E. Valor nutritivo de árboles, arbustos y otras plantas forrajeras para los rumiantes. Pastos y Forrajes. 2002;25:15-20.

71. Lerner-Martínez T, Ceroni A, González CE. Etnobotánica de la comunidad campesina "Santa Catalina de Chongoyape" en el Bosque seco del área de conservación privada Chaparrí-Lambayeque. Ecología Aplicada. 2003;2:14-20.

72. Bermúdez A, Oliveira-Miranda MA, Velázquez D. La investigación etnobotánica sobre plantas medicinales: una revisión de sus objetivos y enfoques actuales. Interciencia. 2005;30:453-9.

73. Bermúdez A, Velázquez D. Etnobotánica médica de una comunidad campesina del estado Trujillo, Venezuela: un estudio preliminar usando técnicas cuantitativas. Rev Fac Farm. 2002;44:2-6.

74. Scarpa GF. Medicinal plants used by the Criollos of Northwestern Argentine Chaco. J Ethnopharmacol. 2004; https://doi.org/10.1016/j.jep.2003.12.003.

75. Henao J, Muñoz LJ, Ríos VE, Padilla L, Giraldo GA. Evaluación de la actividad antimicrobiana de los extractos de la planta Lippia origanoides HBK cultivada en el Departamento del Quindío. Rev Invest Univ Quindio. 2009; 19:159-64.

76. Fomogne-Fodjoa MCY, Ndintehb DT, Olivierc DK, Kempgensa P, van Vuurenc S, Krausea RWM. Secondary metabolites from Tetracera potatoria stem bark with antimycobacterial activity. J Ethnopharmacol. 2017; https:// doi.org/10.1016/j.jep.2016.11.027.

77. Borchert R. Soil and stem water storage determine phenology and distribution of tropical dry forest trees. Ecology. 1994;75:1437-49.

78. Pizano C, García H, editors. El Bosque Seco Tropical en Colombia. Bogotá: Instituto de Investigación de Recursos Biológicos Alexander von Humboldt; 2014.

79. Carrillo-Rosario T, Moreno G. Importancia de las plantas medicinales en el autocuidado de la salud en tres caseríos de Santa Ana Trujillo, Venezuela. Rev Fac Farm. 2006;48:21-8.

80. Giraldo D, Baquero E, Bermúdez A, Oliveira-Miranda MA. Caracterización del comercio de plantas medicinales en los mercados populares de Caracas, Venezuela. Acta Botanica Venezuélica. 2009;32:267-301.

81. Jaramillo MA, Castro M, Ruiz-Zapata T, Lastres M, Torrecilla P, Lapp M, et al. Estudio etnobotánico de plantas medicinales en la comunidad campesina de Pelelojo, municipio Urdaneta, estado Aragua, Venezuela. Ernstia. 2014;24: 85-110.
82. Martínez-Pérez A, López PA, Gil-Muñoz A, Cuevas-Sánchez JA. Plantas silvestres útiles y prioritarias identificadas en la Mixteca Poblana, México. Acta Bot Mex. 2012;98:73-98.

83. Ticktin T, de la Pefia G, Ilsley C, Dalle S, Johns T. Participatory ethnoecological research for conservation: lessons from case studies in Mesoamerica. In: Stepp JR, Wyndham ES, Zarger RK, editors. Ethnobiology and biocultural diversity: Proceedings of the Seventh International Congress of Ethnobiology. University of Georgia Press; 2002. p. 575-584.

84. Garibay-Orijel R, Caballero J, Estrada-Torres A, Cifuentes J. Understanding cultural significance, the edible mushrooms case. J Ethnobiol Ethnomed. 2007; https://doi.org/10.1186/1746-4269-3-4.

85. Narváez-Eraso MT. Usos de la biodiversidad del resguardo indígena de Chiles-Nariño. Revista Criterios. 2010;81:91.

86. Marín-Corba C, Cárdenas-L D, Suárez-Suárez S. Utilidad del valor de uso en etnobotánica. Estudio en el departamento de Putumayo (Colombia). Caldasia 2005; 27:89-101

87. Sánchez M., Duque A, Miraña P, Miraña E, Miraña J. Valoración del uso no comercial del bosque - Métodos en Etnobotánica Cuantitativa. In: Duivenvoorden JF, Balslev H, Cavelier J, Grandez C, Tuomisto H, Valencia, R., editors. Evaluación de recursos vegetales no maderables en la Amazonía noroccidental. Amsterdam: IBED, Universiteit van Amsterdam; 2001.

88. Tuñón E. Género y Medio ambiente. México: Ecosur-Semarnat-Plaza y Valdés; 2003.

89. Sánchez-Núñez E, Espinosa G. Mujeres indígenas y medio ambiente: una reflexión desde la región de la mariposa monarca. In: Tuñón E, editor. Género y Medio ambiente. México: Ecosur-Semarnat-Plaza y Valdés; 2003. p. 129-44.

90. Hurtado R, Moraes R. Comparación del uso de plantas por dos comunidades campesinas del bosque tucumano-boliviano de Vallegrande (Santa Cruz, Bolivia). Ecología en Bolivia. 2010;45:20-54.

91. Canales M, Hernández T, Caballero J, Romo de Vivar A, Durán A, Lira R. Análisis cuantitativo del conocimiento tradicional de las plantas medicinales en San Rafael, Coxcatlán, Valle de Tehuacán-Cuicatlán, Puebla, México. Acta Bot Mex. 2006;75:21-43.

92. Arango S. Estudios etnobotánicos en los Andes Centrales (Colombia): Distribución del conocimiento del uso de las plantas según características de los informantes. Lyonia. 2004:7:89-104.

93. Voeks RA, Leony A. Forgetting the Forest: assessing medicinal plant erosion in eastern Brazil. Econ Bot. 2004:58:5294-306.

94. Gómez-Beloz A. Plant use knowledge of the Winikina Warao: the case for questionnaires in ethnobotany. Econ Bot. 2002;56:231-41.

95. Kumar M, Kumar P. Valuation of the ecosystem services: a psycho-cultural perspective. Ecol Econ. 2008; https://doi.org/10.1016/j.ecolecon.2007.05.008.

\section{Submit your next manuscript to BioMed Central and we will help you at every step:}

- We accept pre-submission inquiries

- Our selector tool helps you to find the most relevant journal

- We provide round the clock customer support

- Convenient online submission

- Thorough peer review

- Inclusion in PubMed and all major indexing services

- Maximum visibility for your research

Submit your manuscript at www.biomedcentral.com/submit 